\title{
Ditadura militar brasileira e memórias femininas
}

\author{
Brazilian military dictatorship and female memoirs
}

Príscila Paula de Sousa*

\begin{abstract}
Resumo: O presente artigo analisa as memórias de algumas mulheres que estiveram no cárcere durante a ditadura militar no Brasil, através de seus relatos em entrevistas e depoimentos, afim de entender quais foram as formas por elas encontradas para resistir ao que viveram no período, não se deixando paralisar pelo terror imposto pelos aparatos repressivos. Trata-se também, de analisar como o ato de contar o que houve é também uma forma de contar-se, de estruturar sua subjetividade e buscar uma identidade. Essas mulheres viram e ainda veem suas vidas intimas arrastadas para o público, aprenderam a cuidar do outro e criar relações de solidariedade dentro das prisões, o que as ajudou a resistir. Assim, essas sobreviventes necessitam ter seu lugar e histórias tratados pela historiografia, afim de que não se esqueça que foram parte importante da luta resistente no período ditatorial.
\end{abstract}

Palavras-chave: Ditadura militar, Memórias femininas, Resistências

\begin{abstract}
This article analyzes the memoirs of some women that have been incarcerated during military dictatorship in Brazil by means of their narratives obtained in interviews and testimonials in order to understand which ways that they found to resist what they lived at that time, not allowing that the terror imposed by the repressive apparatus paralyzed them. It also aims to assay how the attitude of talk about what happened is a way to structure their subjectivity and seek an identity. These women had and still have their lives and intimacy exposed to the public, as well as learned to care for others and to create relations of solidarity within the prisons, which helped them to survive. Therefore, as survivors they need to have their places and stories treated by
\end{abstract}

\footnotetext{
* Mestranda em História na Universidade Estadual de Campinas, Campinas/SP, Brasil. Bolsista Capes. E-mail: priscila.paula.sousa@gmail.com
}

(c) EY Direito autoral e licença de uso: Este artigo está licenciado sob uma Licença Creative Commons. Com essa licença você pode compartilhar, adaptar, para qualquer fim, desde que atribua a autoria da obra, forneça um link para a licença, e indicar se foram feitas alterações. 
historiography for the purpose of being remembered as an important part of the resistance fight in the period.

Keywords: Military dictatorship, Women memoirs, Resistance.

\section{Introdução}

O terror, a repressão e o medo que se instauram em meio a uma ditadura militar, muitas vezes fazem com que os indivíduos percam suas capacidades e forças para resistir às condições sub-humanas às quais estão submetidos. Segundo Pilar Calveiro, "o irmão gêmeo do terror é a paralisia". Sendo, pois, todo o aparato da Ditadura Militar brasileira, de 1964 a 1985, e suas ações oficiais, geradoras de um terror generalizado, a paralisação seria uma atitude compreensível e previsível. Algumas pessoas, porém, resistiram à repressão que, nesse período, se instaurava sobre todos os âmbitos de suas vidas, conseguindo sair da esperada inércia e não permitindo que a prisão, tomada e vilipendio de seus corpos se estendesse para seus ideais de liberdade e luta. Veremos também que uma vida pós-torturas é uma vida resistente em si, que luta para não se entregar à dor e não permitir que o medo e a revolta a paralise e, ao invés disso, continua lutando por justiça e esclarecimento. "Tanto a onipotência do sequestrador quanto a impotência absoluta do sequestrado são ilusórias. Qualquer poder reconhece um limite, e diante de qualquer poder existe uma possibilidade de resistência". ${ }^{2}$

Dentre essas vidas resistentes, veremos o caso de cinco mulheres. São elas: Criméia Alice de Almeida Schmidt, participante da guerrilha do Araguaia e presa pela segunda vez no DOI-CODI/SP (Destacamento de Operações e Informações-Centro de Operações de Defesa Interna), no dia 29 de dezembro de 1972; Rosemary Nogueira (Rose Nogueira), jornalista, presa em 04 de novembro de 1969 no DEOPS/SP (Departamento de Ordem Política e Social de São Paulo) por ceder sua residência para que alguns militantes fizessem reuniões, das quais ela e o marido não participavam; ${ }^{3}$ Maria Amélia de Almeida Teles (Amelinha), integrante do PC do B (Partido Comunista do Brasil), presa pela segunda vez em 28 de dezembro de 1972, também no DOI-CODI/SP sob acusação de apoiar a guerrilha do Araguaia; ${ }^{4}$ Ieda Akselrud Seixas, presa em 16 de abril de 1971 no mesmo DOI-CODI/SP, por ser filha de Joaquim Alencar de Seixas e irmã de Ivan Akselrud Seixas, tendo passado por diversos presídios até ser solta por falta de provas; ${ }^{5}$ Elza Ferreira Lobo, presa no DEOPS/SP em 10 de junho de 1969, teve sua prisão vinculada à Diógenes de Arruda Câmara, líder do PCdoB e com quem tinha um vinculo profissional, mas não militante. ${ }^{6}$

A opção por analisar testemunhos femininos dá-se pois os mesmos são pouco explorados nos trabalhos historiográficos e biográficos/autobiográficos 
sobre o período 7 e porque "nunca é demais lembrar quanto as mulheres estiveram presentes na resistência às ditaduras implantadas na América Latina". ${ }^{8}$ Além disso, à elas, são aplicados atos repressivos específicos, como por exemplo, a violência de cunho sexual e a subversão da maternidade em tortura psicológica. Outro motivo é que os testemunhos femininos são, normalmente, mais ricos em detalhes e diferem dos masculinos pelo lugar de onde se detém a palavra e o que é escolhido para relatar. ${ }^{9}$

O lugar de fala das mulheres é, historicamente, um lugar de fala marcado pela opressão masculina. No caso das mulheres caçadas pelo regime militar, o lugar de fala de uma presa 'subversiva' era duplamente opressor: sofria a generalizada opressão por ser mulher e, somada a isso, a opressão do oficial militar carcereiro/interrogador/torturador. Não nos enganemos, porém, acreditando que tal opressão partia somente dos representantes do Estado. Muitas são as memórias de preconceito e de tentativas de subjugas as militantes femininas nos próprios partidos de esquerda. Maria Amélia Teles foi expulsa do Partido Comunista, juntamente com duas companheiras, em 26 de agosto de 1987, por ser uma militante feminista e por não desistir da causa dos desaparecidos políticos, o que era considerado pelo PC do B uma perda de tempo, deveria se focar na busca de votos e de pessoas que se filiassem ao partido e não se preocupar com a condição da mulher ou com os corpos escondidos pelo Estado. ${ }^{10}$ Ainda sobre a condição feminina, discorre sobre a condição da mulher militante:

Vivíamos numa ditadura, as mulheres participaram efetivamente na luta contra a ditadura e, evidentemente, que nós sentimos o peso da discriminação histórica contra nós. Seja na vida clandestina, seja nas prisões, nas sessões de tortura, enfim, na luta guerrilheira, na luta urbana, na luta rural, em todos os espaços nós fomos aprendendo a ter consciência de que a nossa luta era maior, é bem maior que a dos homens, é mais longa... Essas mulheres foram muito revolucionárias. Elas fizeram uma dupla revolução, tanto na luta política do país, como na luta do cotidiano. ${ }^{11}$

Essas mulheres, que viveram duramente e intensamente a Ditadura Militar, buscam ainda hoje, a partir de suas memórias, compreender seus sentimentos frente aos acontecimentos pelos quais passaram e, dessa maneira, tecem construções de suas subjetividades. Ao longo do texto podemos perceber que o vivido no período é elaborado e reelaborado por elas, muitas vezes através de seus depoimentos, e que esse mesmo depoimento é também uma forma de fazer lembrar, de usar sua voz e força para que os mortos e desaparecidos, aqueles que não tiveram chance de contar a própria história, sejam lembrados. 
Os testemunhos analisados pelo presente trabalho foram coletados pela internet nos depoimentos de Ieda Akselrud Seixas e Elza Ferreira Lobo para a Comissão Nacional da Verdade; os relatos de Maria Amélia Teles, Criméia Alice de Almeida Schmidt e Rose Nogueira, coletados pela novela Amor e Revolução, produzida pelo SBT (Sistema Brasileiro de Televisão); a reportagem As crianças e a tortura, do Jornal da Record; a contribuição de Amelinha Teles à mesa de debates sobre a Comissão da Verdade, na Escola DIEESE; a entrevista cedida por Rose Nogueira ao apresentador Antônio Abujamra em seu programa Provocações, da Tv Cultura; o depoimento de Elza Lobo para o Memorial da Resistência de São Paulo; a participação de Amelinha Teles no evento 50 anos do Golpe Militar de 1964: Revisitando questões e debates; a palestra proferida por Criméia para a turma da disciplina 'Escrita de si, memória e subjetividades, ministrada pela professora Margareth Rago, na Unicamp; a entrevista feita pelo Canal virtual Causa Operária, com Cesar Augusto Teles e Amelinha teles.

Tais relatos são encarados aqui como meios encontrados por essas mulheres de se reconfigurar e como praticas de subjetivação, ${ }^{12}$ buscando através de tais depoimentos afirmarem suas próprias identidades, ${ }^{13}$ das quais foram muitas vezes apartadas graças aos dispositivos criados para escapar à repressão e ao aparato dessa mesma repressão, cuja intenção era também fazer com que os indivíduos fossem psicologicamente quebrados. Além disso, tais relatos de memórias transparecem como e o quanto um estado de exceção como o ditatorial pode reconfigurar a vida dessas pessoas e suas relações familiares. Margareth Rago demonstra que essa organização e transmissão das memórias - quer oralmente, quer de forma escrita - "são modos de subjetivar-se que possibilitam o redimensionamento dos acontecimentos passados, o encontro de um lugar no presente, a criação de um espaço subjetivo próprio como um abrigo para instalar-se e organizar a própria vida". ${ }^{14}$ Uma possibilidade de realinhar o eu do presente e o eu do passado, tomando o ultimo como forma de se apropriar e compreender melhor o primeiro.

No caso de narrativas de experiências traumáticas isso fica ainda mais evidente. Falar das experiências dolorosas do passado pode assumir um papel terapêutico, como uma forma de diminuir a dor ao reorganizar os fragmentos de memória para transmiti-los e compartilha-los. A quem escuta permanece a sensação de responsabilidade pelo outro, atitude ética do ouvinte. Essa transmissão de lembranças faz com que a memória seja algo definitivo para a História. ${ }^{15}$

A fala de Criméia é marcada por essa busca de identidade e pela importância que a mesma tem para a constituição do seu eu. Em entrevista à Margareth Rago, relembra a dificuldade de não poder revelar quem era aos companheiros quando foi para o Araguaia, onde era conhecida como Alice. Nem mesmo a seu parceiro, André Grabois, filho do chefe do destacamento 
Maurício Grabois, pode dizer seu verdadeiro nome e contar sobre sua vida privada. Igualmente, do companheiro e pai de seu filho, sabia somente o nome de guerrilheiro: José Carlos. ${ }^{16}$

Leonor Arfuch discorre sobre as 'temporalidades da memória', a necessidade de haver um distanciamento temporal para que pessoas que passaram por experiências de trauma consigam transmitir sua experiência anormal. ${ }^{17}$ Voltamos aqui, novamente à Criméia, que muitos anos depois reflete sobre a transmissão de seu passado. Relembra que nem mesmo após sair da prisão pode revelar suas memórias e partilhar sua história, pois todos desacreditavam que tivesse existido tal episódio no Araguaia, deslegitimando sua memória, uma das únicas sobre um movimento do qual poucas pessoas sobreviveram. Algumas vezes, ela mesma preferiu não comentar, pois seria difícil conseguir um emprego dizendo que fazia parte do Partido Comunista do Brasil e esteve na mata preparando-se para uma guerrilha. ${ }^{18}$

Narrar o próprio passado e o de muitos outros companheiros que não podem fazê-lo é um ato de resistência ao esquecimento, é uma forma de divulgar uma história que, se não contada, seria, antes que esquecida, ignorada por muitos. No caso específico da Ditadura Militar, a produção desta narrativa permite dar voz aos assassinados pelo regime, que não podem narrar a si próprios: "uma palavra, neste caso, cuja insistência se opõe ao vazio, à ausência, ao esquecimento. A palavra - a narração - como ato de resistência". ${ }^{19}$

Criméia deixa claro que, tanto quanto for possível, quer relembrar e narrar toda a sua história, para que saibamos o que ocorreu não só com ela, mas com os companheiros militantes que foram assassinados na guerrilha. ${ }^{20} \mathrm{O}$ ato de falar sobre o assunto é também uma forma de resistência e de autobiografia (contar-se), que auxilia na organização do próprio passado. Passado esse muitas vezes negado e modificado pela própria militante devido ao fato de não poder se revelar enquanto Criméia. Não poder falar de si é, para ela, não ter história, não existir. ${ }^{21}$ No entanto, ao recordar e reproduzir suas lembranças sente-se um indivíduo, uma pessoa com passado.

\section{Da vida íntima arrastada para o público}

Leonor Arfuch, já citada nesse artigo, trabalha com os conceitos de 'transformação da intimidade', de Anthony Guiddens e de 'intimidade pública', de Lauren Berlant para pensar os 'pequenos relatos' do sujeito. ${ }^{22}$ Conceitos que se aplicam aos relatos de mulheres que estiveram presas durante a Ditadura Militar, cujo próprio passado, privado e intimo, é transformado em público, por compor uma parte da história do país.

De acordo com a perspectiva de Berlant, aspectos das vidas privadas de tais mulheres são levadas a público, como o caso de Criméia, que se empenha e esforça para narrar detalhes de seu passado que ocorreram em âmbitos particulares da vida. Muitos de nós escolhemos um curso superior, um 
companheiro para uma relação afetiva, temos filhos e irmãos. No caso dessa militante, tudo isso faz parte de uma história que é, não só dela, mas de todos, na qual o estado de exceção teve influencia direta.

Criméia escolhe sua faculdade a partir de uma demanda do PC do B e torna-se enfermeira. A fim de se preparar para a luta armada, vai para a região do Araguaia por uma opção própria. Lá, conhece seu companheiro no contexto da guerrilha e com ele tem um filho, João Carlos. Devido à gravidez, Criméia volta a São Paulo e é presa no DOI-CODI/SP. ${ }^{23} \mathrm{O}$ filho nasce no hospital militar em Brasília, para onde havia sido transferida, e só é amamentado quando os militares permitem. "Quando devolviam meu filho, estava com diarreia, com vômito. E era uma briga constante, né?! Para eu poder ficar com esse meu filho". ${ }^{24}$

Podemos perceber com essas lembranças de Criméria, que a relação de mãe e filho, normalmente comum, íntima e rotineira, torna-se conhecida por muitas pessoas e não ocorre no interior do lar, como se espera. Isso demonstra que esse aspecto da vida privada dessa militante e de seu filho foi tornado duplamente público: primeiro porque o lar foi substituído pela instituição publica prisional e segundo porque essa história foi apresentada e é conhecida por todos nós.

Igualmente, a vida íntima e familiar de Maria Amélia Teles se desenvolveu, durante o período em que esteve encarcerada pelo regime militar, num órgão público. Ela e o marido César Augusto Teles estiveram presos no DOI-CODI/SP. Nos primeiros dias, seus filhos, Janaína de Almeida Teles, de 5 anos e Edson de Almeida Teles, de 4 anos, passavam as tardes no pátio do prédio e as noites numa casa ainda hoje não identificada. ${ }^{25}$ Posteriormente, estiveram sob tutela na casa de um delegado, cunhado de César Augusto Teles, tio que as crianças não conheciam anteriormente. Esse delegado dizia aos 'sobrinhos' que os pais eram terroristas e que não queriam ficar com os filhos, dando continuidade ao processo de tortura psicológica, iniciado no DOI-CODI/SP. ${ }^{26}$

Outra relação marcada pela ditadura e invadida pela vida pública foi a das já citadas: Amelinha e Criméia. Duas irmãs sendo obrigadas a viver sobre as pressões e torturas de um âmbito prisional, cada uma sabendo que a outra estava sendo torturada e tendo a fraternidade usada pelos militares como forma de coação para que revelassem coisas sobre as quais os oficiais queriam saber: estando Criméia grávida, alguns métodos de tortura foram transferidos para a irmã, como os choques na vagina e boca e pancadas na barriga, desaconselhados pelos médicos militares de serem aplicados à gestante. Com isso, Criméia era acusada pelos militares e até mesmo por alguns companheiros de cárcere de ser a responsável pela tortura sofrida pela irmã, já que mantinha-se calada. ${ }^{27}$

A família Seixas também conviveu por meses no sistema carcerário ditatorial e não no lar. Ieda foi presa com a irmã, Iara Akselrud Seixas, a mãe Fanny, após o irmão Ivan e o pai, Joaquim Alencar de Seixas terem sido presos. 
A senhora Fanny, ouviu os gritos do marido sob uma tortura brutal que levou a sua morte e viu seu cadáver sendo retirado do prédio do DOI-CODI/SP. ${ }^{28}$ Mais uma vez, a relação íntima fraternal, paternal e conjugal passa a ocorrer no domínio público e é cerceada pelo Estado. Além disso, a história é relembrada e exposta ao público pela própria Ieda Seixas em seu depoimento à Comissão Nacional da Verdade, em 2013.

Percebemos então que as memórias individuais dessas mulheres fazem parte de uma 'memória coletiva' mais ampla, para usar um termo de Maurice Halbwachs, segundo o qual, "nossas lembranças permanecem coletivas e nos são lembradas por outros, ainda que se trate de eventos em que somente nós estivemos envolvidos e objetos que somente nós vimos". ${ }^{29}$ Assim, a memória relativa ao período ditatorial no Brasil é coletiva, uma vez que diz respeito a acontecimentos que envolvem toda a sociedade e que, portanto, interessam a todos, mas dos quais somente cada uma dessas pessoas, individualmente, pode dar testemunho.

\section{Do cuidado com o outro}

A 'cultura de si', da qual fala o filósofo francês Michel Foucault, é a necessidade de cuidar de si mesmo, de enfatizar a importância das relações de si para consigo. Não nos enganemos, porém, crendo que esse cuidado de si seja unicamente algo individualizante, "tem-se aí um dos pontos mais importantes dessa atividade consagrada a si mesmo: ela não constitui um exercício da solidão, mas sim uma verdadeira prática social". ${ }^{30}$ Através dele, o indivíduo alcança mais facilmente diversas práticas de ajuda e cuidado com o outro "em todo feixe de relações habituais de parentesco, de amizade ou de obrigação (...) O cuidado de si (...) aparece então como uma intensificação das relações sociais." 31

No caso das mulheres que estamos tratando, as praticas de cuidado do outro eram também formas de cuidado de si e subjetivação, incentivo para mantendo-se vivas, não permitindo que toda a culpabilidade que o Estado tentava fazer recair sobre elas - como no caso de Criméia, acusada de ser a responsável por torturar a irmã-e não desistindo de suas vidas e de si mesmas, não permitindo seu apagamento enquanto indivíduo. O cuidado do outro só poderia advir desse cuidado consigo mesmo, uma tentativa de que o outro também não se deixasse vencer e apagar, não se entregasse às incessantes tentativas militares de degradação de suas condições humanas.

Variadas são as formas de cuidado do outro que podemos perceber nas relações entre as presas políticas através de seus depoimentos. Ieda Seixas nos narra que após uma sessão de tortura, ela e os demais presos cantavam em conjunto, a fim de demonstrar àquele que havia sido quebrado pela tortura, que não estava sozinho e dar-lhe forças, numa atitude resistente - não era permitido cantar - e solidária. Sobre a importância de atitudes como essas para a resistir 
a contextos de conflito, demonstra-nos Foucault: "O que faz com que nessas guerras absurdas, grotescas, nesses massacres infernais, as pessoas, apesar de tudo, tenham se sustentado? Sem dúvida, um tecido afetivo". ${ }^{32}$

São vários os relatos de cuidados com a saúde desses mesmos recémtorturados quando eram colocados de volta às suas celas. Solidária, Elza Lobo relembra como cuidava de outros presos e presas quando voltavam arrebentados pela tortura. ${ }^{33}$ Rose Nogueira também foi cuidada por uma colega de cela, Madre Maurina, que a ensinou a fazer uma massagem para que os seios não mais empedrassem devido ao leite materno que ainda possuía, visto que havia dado à luz 33 dias antes de sua prisão. Graças à massagem, suas dores tiveram fim. ${ }^{34}$

Outra forma encontrada pelas ex-presas para cuidar do outro, configurando assim um exemplo dos laços estabelecidos de solidariedade e amizade foi o ato de se tornarem ajudantes na cozinha do presídio. Essa atitude, ressalta Ieda Seixas, foi uma opção e uma maneira de resistência e não de sujeição e alienação. Tanto a citada Ieda Seixas quanto Elza Lobo relembram que optaram por ajudar na cozinha a fim de conseguir servir uma refeição mais digna aos colegas presos. As ordens eram servir primeiro os oficiais, depois os cachorros, as presas e os presos, respectivamente. Facilmente percebemos, diante dessa ordem, que o que sobrava de alimento aos encarcerados era pouca coisa - em quantidade e variedade. A estratégia adotada por Elza Lobo foi, então, esconder um pedaço de carne ou ovo sob o arroz no prato, para que passasse despercebido pelos guardas. A forma de servir a comida também era um ato de cuidado com o outro, pois permitia que isso fosse feito em pratos, ao invés das usuais latas e que esse mesmo prato viesse montado e com aspecto melhor que a comida revirada que recebiam normalmente, como se fosse servida a animais. Servir os pratos era também uma forma de saber o que estava acontecendo nas outras celas, já que a comunicabilidade era proibida. Nos relatos de Elza, fica clara a intenção afetiva do ato de servir a comida: fazer com que o outro se sentisse melhor. ${ }^{35}$ Essa atitude era, simultaneamente, um cuidado do outro e um cuidado de si mesma. Afinal, ao saber que estava fazendo algo que dava aos indivíduos ali um tratamento um pouco mais próximo do humano era, para ela, algo edificador.

Elza Lobo, em seu depoimento ao Memorial da Resistência de São Paulo - antiga sede do DEOPS/SP, onde esteve presa - relembra que em um Natal, pediu à sua família que trouxesse flores para que ela distribuísse aos outros presos. A família trouxe cravos vermelhos e ela entregou a cada um dos presos, pois acreditava que seria um carinho revigorante para os colegas presos ver uma flor, algo vivo naquele lugar. "Sabe assim quando você quer levantar a moral também das pessoas? Então se de um lado você tem uma agressão muito forte, você tenta amenizar né?! Passar um natal sem nada, tem que ter alguma coisa." ${ }^{36}$ 


\section{Dos símbolos do feminino usados para torturar}

Ao falar de mulheres encarceradas pela Ditadura Militar é importante que se debruce sobre as especificidades na forma como as mesmas eram tratadas pelos agentes repressivos e na maneira como a tortura era imposta a elas. Como exemplo dessa exploração de suas características femininas, podemos citar seus próprios corpos, suas sexualidades e a maternidade. Além disso, estar no ambiente prisional já era bastante opressor: "O DOI CODI não era só uma questão de você ser torturado, era o que você presenciava e o clima, os gritos ficam na tua cabeça, não tem jeito. Não precisa botar a mão em você!"’37

Ponto comum nos testemunhos de todas essas mulheres são os abusos de caráter sexual, físicos e psicológicos sofridos na prisão. Ieda Seixas relata ter sido abusada por um dos oficiais em um banheiro do DOI-CODI/SP, enquanto outros a seguravam. ${ }^{38}$ Amelinha, ainda na Cadeira do Dragão (cadeira forrada com placas de metal que favoreciam o contado das correntes elétricas ao corpo), recém torturada, presenciou um dos oficiais masturbar-se na sua frente e jogar seu sêmen sobre ela, que vomitou, demonstrando sua repulsa ao ato. ${ }^{39}$

Logo no início das sessões de interrogatório - que na maioria das vezes era sinônimo de tortura - eram despidas de suas roupas, como forma de despilas de uma proteção - as vestimentas são uma espécie de proteção do corpo quando se está em público - e fazê-las sentirem-se ainda mais escancaradas diante do torturador. ${ }^{40} \mathrm{~A}$ retirada das vestimentas pode ser encarada como uma forma de fazer com que o prisioneiro se sinta transparente, incapaz de esconder qualquer coisa de seus algozes.

A maternidade, símbolo máximo da sacralização da mulher devido ao seu importante papel na manutenção da espécie era também distorcida quando a mãe era uma militante. Ao contrario de ser tida como uma mulher respeitável, que dá a luz a um indivíduo, é tida como um ser vulgar. ${ }^{41}$ No caso de Rose Nogueira, maternidade e violência sexual estavam atreladas.Tendo tido seu filho poucos dias antes de ser capturada em sua residência, ainda tinha leite nos seios e, por isso, era chamada de "vaca leiteira" pelos soldados. Também por conta do parto recente, ainda sofria com o sangramento de 40 dias após a gravidez e ficava com mau cheiro, favorecido pelas condições de higiene precárias. Esse odor fazia com que um dos soldados reclamasse e batesse nela, antes de estupra-la: "ele me tirava a roupa, debruçava em cima de uma mesa e me batia muito, abusava de todo jeito. Um horror! Eu tinha o leite, aí eu apanhava também porque era fedida. Quando ele chegava perto de mim, tava aquele cheiro ruim". ${ }^{42}$

Tanto Amelinha, quanto Criméia e Rose Nogueira tiveram seus filhos utilizados como instrumento de tortura psicológica. Os filhos de Amelinha eram levados à sua cela e à do marido e apresentados aos pais, machucados pelas sessões de tortura. Essa mãe ouviu a filha Janaína perguntar-lhe: "por que você está azul e o pai está verde?" ${ }^{43}$ Sobre esse episódio, Edson relembra: 
Aí eu ouvi a voz da minha mãe me chamando: 'Edson, Edson'. Eu reconheci na hora a voz e quando eu olhei para traz eu não reconheci a pessoa, porque ela já estava completamente machucada, deformada, roxa. Então, aquela cena ficou marcada. Como é que este corpo que eu não conheço e não reconheço tem a voz aconchegante e familiar da minha mãe? ${ }^{44}$

Aos 8 anos de idade, a pequena Janaína fez o seguinte poema para entregar ao pai, que ainda estava preso: "Preste atenção/ Dói o peito chorar/ Dói os seus olhos chorarem/ Dói nós viver/ Dói ver os outros chorarem/ Dói a natureza chorar/ Dói gostar dos outros". ${ }^{45} \mathrm{O}$ poema é apresentado por ela em um depoimento de 2013, portanto, foi guardado pela filha de Amelinha por todos esses anos. Nessa atitude podemos perceber que Janaína produz um 'arquivamento de si', proposto por Philippe Artières, demonstrando como somos levados e necessitamos de arquivar nossas vidas através de inúmeros papeis ou objetos. No caso do poema, especificamente, podemos perceber uma das formas desse arquivamento: "arquivar a própria vida é querer testemunhar". ${ }^{46}$

Esse mesmo arquivamento de si foi negado a João Carlos de Almeida Grabois, filho de Criméia e André Grabois, ao menos no que se refere ao seu relacionamento com o pai, a quem não conheceu e do qual não pode, sequer, guardar uma recordação como um álbum de fotos, documentos comuns ou objetos. Afinal, os pais eram militantes e, tendo André sido morto no Araguaia quando João Carlos tinha apenas oito meses, a essa família foi negada pelo Estado não só a convivência, mas qualquer vestígio concreto de suas memórias que pudessem ser arquivados. ${ }^{47}$

Pilar Calveiro, ao falar sobre as prisões e torturas durante a ditadura militar argentina, demonstra que os oficiais sentiam-se orgulhosos de possuir um poder de morte sobre os prisioneiros. Decidiam não só quando os mesmos deveriam, mas quando poderiam morrer, visto que os suicídios eram impedidos. Para além disso, possuíam também o 'poder de vida', ao decidir qual criança nasceria dentro da prisão, qual viveria em detrimento da morte da mãe e em qual dos casos mãe e filho morreriam. Assim, os "doadores de morte e doadores de vida coincidem". ${ }^{48}$

João Carlos era alvo de ameaças desde o útero da mãe, tendo os militares do hospital o poder citado por Calveiro de dar-lhe ou tirar sua vida. Os oficiais diziam à Criméia que ficariam com seu filho caso ele fosse homem, forte $\mathrm{e}$ branco, demonstrando todo o preconceito de cor e gênero presente naqueles homens. Criméia relata que enorme foi o seu desespero por ter o filho nascido homem, branco e de olhos claros. A adoção, porém, para sua felicidade não se concretizou, e depois de algum tempo João Carlos foi entregue à família da mãe. ${ }^{49}$ Durante esses meses em que o filho esteve próximo à ela, a tortura não era menor, afinal, a militante sabia que a qualquer momento poderiam fazer algum mal à criança. 
Já Rose Nogueira, passou pela agonia de ter o filho, Carlos Guilherme Clauset, sido levado ao prédio do DEOPS/SP, na companhia dos sogros de Rose, sob o pretexto de que poderiam visitar a nora e o filho, Luiz Roberto Clauset, também preso. Durante o tempo em que permaneceram no edifício, os carcereiros vinham lhe avisar que o filho estava lá e que ela sabia que podiam lhe machucar, provocando-lhe queimaduras ou quebrando algum membro. Mas, não lhe foi causado nenhum dano físico. ${ }^{50}$

\section{Da resistência}

Podemos perceber então, que os atos militares eram sempre feitos na tentativa de desestabilizar as prisioneiras. Quebrar seus corpos, violentar seus sexos, ameaçar seus entes queridos e, por fim, abala-las psicologicamente e reduzir sua condição de ser humano. Isso, porém, não foi possível de se realizar com a vida dessas mulheres durante suas prisões, pois, percebemos em seus depoimentos que, apesar de tudo isso, realizaram pequenos atos de resistência e construíram laços de amizade, solidariedade e fraternidade que lhes permitiram manterem-se vivas. ${ }^{51} \mathrm{Um}$ exemplo de que também após as prisões há resistência contra esse sistema destruidor é o depoimento de Ieda Seixas, 42 anos depois após os acontecimentos: "Uma coisa que tudo isso não conseguiu me tirar foi a alegria (...) A alegria, a minha dignidade (...) E nunca me humilharam porque aqueles caras não eram pessoas, eram seres(...). Eu tenho só ódio e não ocupam meu pensamento. ${ }^{52}$

Às acusações de ser a responsável pela tortura da irmã e, posteriormente, às tentativas de fazer com que se sentisse responsável pelo sofrimento de seu bebê na prisão, Criméia relata que respondia a si mesma "não sou eu a culpada, a culpa é da ditadura". ${ }^{53}$ Talvez venha dessa convicção a força incomensurável que se percebe nessa mulher e em sua fala. É a forma como conseguiu e consegue preservar sua subjetividade, sem se deixar culpar ou cooptar pelas pressões do sistema.

Podemos perceber em Criméia, Amelinha, o marido César e os filhos: João Carlos Grabois, Janaína e Edson Teles, que, tanto não permitiram que o terror pelo qual passaram os paralisasse, que continuam reunindo documentos referentes ao período ditatorial e trabalham junto ao Instituto de Medicina Legal da Universidade de São Paulo para auxiliar na construção de mais uma narrativa sobre esse passado doloroso para sua família e também para o país. ${ }^{54}$ Criméia e Amelinha também fazem parte da Comissão de Mortos e Desaparecidos políticos.

Rose Nogueira afirma que "se tem uma coisa que os torturadores tinham razão, era dizer que marca de tortura não passa. Não passa!" 55 No entanto, cada uma das mulheres que foram analisadas nesse trabalho encontraram uma forma de lidar com essas marcas e não se deixaram quebrar pelas pressões ou pelo aparato de tortura, resistindo e narrando essa resistência, anos depois. 
Cinquenta anos após o golpe, essas mulheres ainda estão dispostas a dialogar e relatar o que lhes aconteceu em função do Regime Militar, exemplos disso, são os testemunhos analisados nesse trabalho. Se o fazem é porque sabem a importância de conhecer os acontecimentos dessa "página infeliz da nossa história", como lembra Chico Buarque, para que algo semelhante não volte a acontecer e para que se veja a importância e necessidade de se rever a Lei da Anistia, segundo a qual não só os torturados e perseguidos, mas os torturadores e perseguidores encontram-se isentos de qualquer julgamento. Ao fim, testemunhar, contar e recontar é fundamental para que todas as perdas humanas, materiais e imateriais, todas as vidas e famílias interrompidas pelo regime, nunca sejam esquecidas.

\section{Notas}

1 CALVEIRO, Pilar. Poder e Desaparecimento: Os campos de concentração na Argentina. São Paulo: Boitempo, 2013, p. 60.

2 Ibidem, p. 64.

3 NOGUEIRA, Rosemary. Amor e Revolução: depoimento. [2011]. São Paulo: Sistema Brasileiro de Televisão. Disponível em: <http://www.youtube.com/watch?v=hbyFh-A8yz8k>. Acesso em: 15/11/2013.

4 TELES, Maria Amélia de Almeida. 50 anos do Golpe de 64: Continuidades e rupturas: debate [25 abr. 2014]. São Paulo: Escola Dieese de Ciência do Trabalho. Disponível em: $<$ https://www.youtube.com/watch?v=ALOwX8PA7wQ>. Acesso em: 04/09/2014.

5 SEIXAS, Ieda Akselrud. Ieda Seixas e Elza Lobo: depoimento [14 abr. 2013]. São Paulo: Comissão Nacional da Verdade. Disponível em: $<\mathrm{https}$ ://www.youtube.com/watch?v=5duiX4Uxc9c>. Acesso em: 03/10/2013.

6 LOBO, E. Ieda Seixas e Elza Lobo: depoimento [14 abr. 2013]. São Paulo: Comissão Nacional da Verdade. Disponível em: <https://www.youtube.com/watch?v=5duiX4Uxc9c>. Acesso em: 03/10/2013.

7 RAGO, Margareth. Desejos de Memória. Labrys Estudos Feministas. Dossiê 'Memórias insubmissas, n.15. 2009.

8 ROSA, Susel. O. Mulheres, ditaduras e memórias. São Paulo: Intermeios, 2013, p. 307.

9 ARFUCH, Leonor. Mujeres que narran: trauma e memória. Labrys Estudos Feministas. Dossiê: Memoria y Autobiografia. Jan/Dez 2009. Disponível em: $<\underline{\text { http://www.tanianavar- }}$ roswain.com.br/labrys/labrys15/sumarioditadura.htm>. Acesso em: 17/09/2013.

10TELES, Maria Amélia de Almeida. Entrevista com Amelinha e Cesar Augusto Teles: depoimento. [12 out. 2012]. São Paulo: Causa Operária TV. Disponível em: $<$ https://www. youtube.com/watch?v=OApkFxymEGU>. Acesso em: 05/09/2014.

11 Idem. Depoimento. [16 jan. 2014]. Canal Maria Angélica Lemos. Disponível em: <https:// www.youtube.com/watch? $v=$ pTbBRQvzrQ $>$. Acesso em: 04/09/2014.

12 Sobre o conceito de subjetivação ver: FOUCAULT, Michel. História da Sexualidade II. Rio de Janeiro: Graal, 1984, p. 14. 
13 ARFUCH, Leonor. Mujeres que narran: trauma e memória. Labrys Estudos Feministas. Dossiê: Memoria y Autobiografia. Jan/Dez 2009. Disponível em: $<\underline{\text { http://www.tanianavar- }}$ roswain.com.br/labrys/labrys15/sumarioditadura.htm >. Acesso em: 17/09/2013.

14 RAGO, Margareth. Memórias da clandestinidade: Criméia Alice de Almeida Schmidt e a Guerrilha do Araguaia. In: PEDRO, Joana; WOLFF, Cristina. Gênero, Feminismos e Ditaduras no Cone sul. Florianópolis: Ed. Mulheres, 2010, p. 3.

15 ARFUCH, Leonor. Op. cit.

16 RAGO, Margareth, op. cit.

17 ARFUCH, Leonor, op. cit.

18 RAGO, Margareth. Memórias da clandestinidade: Criméia Alice de Almeida Schmidt e a Guerrilha do Araguaia. In: PEDRO, Joana; WOLFF, Cristina. Gênero, Feminismos e Ditaduras no Cone sul. Florianópolis: Ed. Mulheres, 2010.

19 ARFUCH, Leonor. Mujeres que narran: trauma e memória. Labrys Estudos Feministas. Dossiê: Memoria y Autobiografia”. Jan/Dez 2009, p. 13. [Tradução do autor]. Texto original: "una palabra, en este caso, cuya insistência se opone al vacío, a la ausência, al olvido. La palabra - la narración - como acto de resistência". Disponível em: $<\underline{\text { http: } / / \text { www.tanianavar- }}$ roswain.com.br/labrys/labrys15/sumarioditadura.htm>. Acesso em: 17/09/2013.

20 SCHMIDT, Criméia Alice de Almeida. A vida militante e o período da ditadura. Campinas, Unicamp, 28 abr. 2013. Palestra oferecida aos alunos do curso "Escrita de si, Memória e Subjetividade", ministrado pela Prof ${ }^{a}$. Dra. Margareth Rago.

21 RAGO, Margareth. Memórias da clandestinidade: Criméia Alice de Almeida Schmidt e a Guerrilha do Araguaia. In: PEDRO, Joana; WOLFF, Cristina. Gênero, Feminismos e Ditaduras no Cone sul. Florianópolis: Ed. Mulheres, 2010.

22 ARFUCH, Leonor. Mujeres que narran: trauma e memória. Labrys Estudos Feministas. Dossiê: Memoria y Autobiografia”. Jan/Dez 2009, p. 13. [Tradução do autor]. Texto original: "una palabra, en este caso, cuya insistência se opone al vacío, a la ausência, al olvido. La palabra - la narración - como acto de resistência". Disponível em: $<\underline{\text { http: } / / \text { www.tanianavar- }}$ roswain.com.br/labrys/labrys15/sumarioditadura.htm>. Acesso em: 17/09/2013.

23 RAGO, Margareth. op. cit.

24 SCHMIDT, Criméia Alice de Almeida. Amor e Revolução: depoimento. [2011]. São Paulo: Sistema Brasileiro de Televisão. Disponível em: $<\mathrm{http}$ :/www.youtube.com/watch? $\mathrm{v}=\mathrm{r}$ z0ekhjmvRc>. Acesso em: 15/11/2013.

25 TELES, Janaína de Almeida. As crianças e a tortura: depoimento. [10 jun. 2013]. São Paulo: Jornal da Record: Disponível em: <http://www.youtube.com/watch?v=kRQdjfMdfts>. Acesso em: 19/11/2013.

26 TELES, Maria Amélia de Almeida. Entrevista com Amelinha e Cesar Augusto Teles: depoimento. [12 out. 2012]. São Paulo: Causa Operária TV. Disponível em: <https://www. youtube.com/watch?v=OApkFxymEGU>. Acesso em: 05/09/2014.

27 SCHMIDT, Criméia Alice de Almeida. A vida militante e o periodo da ditadura. Campinas, Unicamp, 28 abr. 2013. Palestra oferecida aos alunos do curso "Escrita de si, Memória e Subjetividade", ministrado pela Prof ${ }^{\mathrm{a}}$. Dra. Margareth Rago.

28 SEIXAS, Ieda Akselrud. Ieda Seixas e Elza Lobo: depoimento [14 abr. 2013]. São Paulo: Comissão Nacional da Verdade. Disponível em: <https://www.youtube.com/watch?v=5duiX4Uxc9c>. Acesso em: 03/10/2013. 
29 HALBWACKS, Maurice. A Memória Coletiva. São Paulo: Centauro, 2006, p. 30.

30 FOUCAULT, Michel. História da Sexualidade III: O cuidado de si. Rio de Janeiro: Edições Graal, 1985, p. 57.

31 Ibidem, p. 58.

32 Idem. De l'amitié comme mode de vie. Gai Pied, 04/1981,. n. 25, pp. 38-39. Entrevista concedida a R. de Ceccaty, J. Danet e J. le Bitoux. Disponível em: <http://psicanaliselacaniana.blogspot.com.br/2009/08/da-amizade-como-modo-de-vida.html >. Acesso em: 10/10/2013.

33 LOBO, Elza Ferreira. Ieda Seixas e Elza Lobo: depoimento [14 abr. 2013]. São Paulo: Comissão Nacional da Verdade. Disponível em: $<\mathrm{https}$ ://www.youtube.com/watch?v=5duiX4Uxc9c>. Acesso em: 03/10/2013.

34 NOGUEIRA, Rosemary. Provocações. [dez. 2012]. São Paulo: TV Cultura. Entrevista concedida a Antônio Abujamra. Disponível em: < http://www.youtube.com/watch?v=7bQpeyvEpkY>. Acesso em: 19/11/2013.

35 LOBO, Elza Ferreira, op. cit.

36 Idem. Depoimento [16 set. 2008]. São Paulo: Memorial da Resistência.

37 SEIXAS, Ieda Akselrud. Ieda Seixas e Elza Lobo: depoimento [14 abr. 2013]. São Paulo: Comissão Nacional da Verdade. Disponível em: $<\mathrm{https}$ ://www.youtube.com/watch?v=5duiX4Uxc9c>. Acesso em: 03/10/2013.

38 Ibidem.

39 TELES, Maria Amélia de Almeida. Mulheres e Ditaduras. Campinas: Unicamp, 12 mar. 2014. Exposição no evento 50 anos do Golpe Civil-Militar de 1964: Revisitando Questões e Debates.

40 CALVEIRO, Pilar. Poder e Desaparecimento: Os campo de concentração na Argentina. São Paulo: Boitempo, 2013.

41 JOFFILY, Olivia Rangel. "O corpo como campo de batalha". In: PEDRO, Joana; WOLFF, Cristina. Gênero, Feminismos e Ditaduras no Cone sul. Florianópolis: Ed. Mulheres, 2010.

42 NOGUEIRA, Rose. Amor e Revolução: depoimento. [2011]. São Paulo: Sistema Brasileiro de Televisão. Disponível em: <http://www.youtube.com/watch?v=hbyFh-A8yz8k>. Acesso em: 15/11/2013.

43 TELES, Maria Amélia de Almeida. Amor e Revolução: depoimento. [2011]. São Paulo: Sistema Brasileiro de Televisão. Disponível em: $<\mathrm{http}: / / \mathrm{www} . y o u t u b e . c o m / \mathrm{watch}$ ? $=\mathrm{kFq}-$ m0OcJDDk>. Acesso em: 15/11/2013.

44 TELES, Edson de Almeida. As crianças e a tortura: depoimento. [10 jun. 2013]. São Paulo: Jornal da Record: Disponível em: <http://www.youtube.com/watch?v=kRQdjfMdfts>. Acesso em: 19/11/2013.

45 TELES, Janaína de Almeida. As crianças e a tortura: depoimento. [10 jun. 2013]. São Paulo: Jornal da Record: Disponível em: <http://www.youtube.com/watch?v=kRQdjfMdfts>. Acesso em: 19/11/2013.

46 ARTIÈRES, Philippe. Arquivar a própria vida. Estudos Históricos. Rio de Janeiro, v. 11, n. 21, 1998, p. 9-34, p. 25. Disponível em: http://bibliotecadigital.fgv.br/ojs/index.php/reh/ article/view/2061/1200>. Acesso em: 17/08/2013. 
47 RAGO, Margareth. Memórias da clandestinidade: Criméia Alice de Almeida Schmidt e a Guerrilha do Araguaia. In: PEDRO, Joana; WOLFF, Cristina. Gênero, Feminismos e Ditaduras no Cone sul. Florianópolis: Ed. Mulheres, 2010.

48 CALVEIRO, Pilar. Poder e Desaparecimento: Os campo de concentração na Argentina. São Paulo: Boitempo, 2013, p. 64.

49 SCHMIDT, Criméia Alice de Almeida. Amor e Revolução: depoimento. [2011]. São Paulo: Sistema Brasileiro de Televisão. Disponível em: $<\mathrm{http}$ :/www.youtube.com/watch?v=rz0ekhjmvRc>. Acesso em: 15/11/2013.

50 NOGUEIRA, Rosemary. Provocações. [dez. 2012]. São Paulo: TV Cultura. Entrevista concedida a Antônio Abujamra. Disponível em: < http://www.youtube.com/watch?v=7bQpeyvEpkY>. Acesso em: 19/11/2013.

51 ROSA, Susel. O. Mulheres, ditaduras e memórias. São Paulo: Intermeios, 2013.

52 SEIXAS, Ieda Akselrud. Ieda Seixas e Elza Lobo: depoimento [14 abr. 2013]. São Paulo: Comissão Nacional da Verdade. Disponível em: $<$ https://www.youtube.com/watch?v=5duiX4Uxc9c>. Acesso em: 03/10/2013.

53 SCHMIDT, Criméia Alice de Almeida. A vida militante e o período da ditadura. Campinas, Unicamp, 28 abr. 2013. Palestra oferecida aos alunos do curso "Escrita de si, Memória e Subjetividade", ministrado pela Prof ${ }^{\mathrm{a}}$. Dra. Margareth Rago.

54 RAGO, Margareth. Memórias da clandestinidade: Criméia Alice de Almeida Schmidt e a Guerrilha do Araguaia. In: PEDRO, Joana; WOLFF, Cristina. Gênero, Feminismos e Ditaduras no Cone sul. Florianópolis: Ed. Mulheres, 2010.

55 NOGUEIRA, Rose. Amor e Revolução: depoimento. [2011]. São Paulo: Sistema Brasileiro de Televisão. Disponível em: <http://www.youtube.com/watch?v=hbyFh-A8yz8k>. Acesso em: 15/11/2013.

Recebido em 08/10/2017

Aprovado em 10/08/2018 